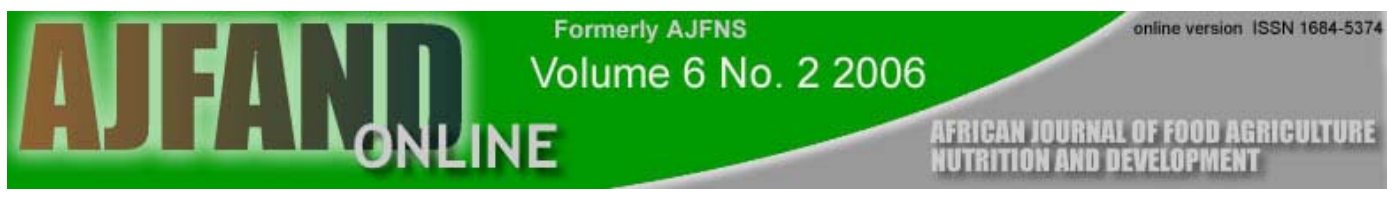

\title{
FACTORS INFLUENCING BREASTFEEDING PRACTICES IN EDO STATE, NIGERIA
}

\section{Lilian I Salami}

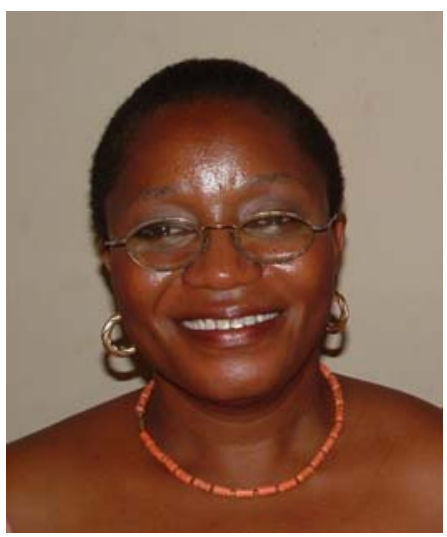

Lilian Salami

Department of Vocational and Technical Education University of Benin

Ugbowo, Benin City. Nigeria

lilliansalami@yahoo.com, lilsal@uniben.edu 


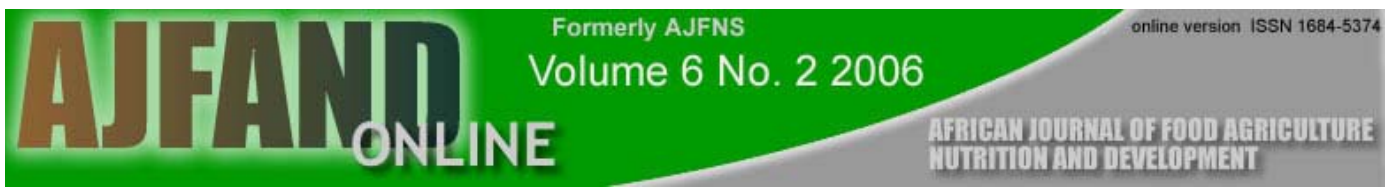

\begin{abstract}
The superiority of breast milk compared to other types of milk for the nourishment of the human infant offering better health benefits, has been established by various research publications. Early childhood is characterized by rapid growth, maturation of tissues and remodeling of organs. Breastfeeding is the optimal method for feeding infants. All the nutritional needs for most of these children are provided by breast milk in the right amounts and duration. In Nigeria however, young infants may not benefit from such a practice as a result of poor early initiation and the use of other liquids undermining breast milk. The purpose of this study was to determine factors influencing breastfeeding practices in Edo State, Nigeria. A questionnaire and group interviewed were the instruments used. Data was collected from 600 randomly selected mothers of children aged 4-24 months, who visited four antenatal and children clinics. The data obtained were analysed using percentiles, means and standard deviations. Although the findings indicated that 82 per cent of the mothers practiced breastfeeding, 66 per cent supplemented with corn gruel and glucose water, and 14 per cent used herbal brew. Only 20 per cent practiced exclusive breastfeeding. Of the possible variables affecting breastfeeding practices, proximity to baby with a mean score of 4.63 ( $\mathrm{SD} \pm 0.66$ ) out of 5.00 was the most influential, and the least, family background, had a mean score of 2.32 ( $\mathrm{SD} \pm 0.92$ ). The findings of the study have implications for health education programmes and breastfeeding practices. Efforts must be intensified to educate prospective mothers on the need and benefits of breastfeeding, and that the UNICEF-WHO Baby Friendly Hospital Initiative must go beyond the designated University Teaching Hospitals to other public and privately owned hospitals. The provision of crèches at the work place or market place will reduce the distance between babies and their mothers and subsequently increase the levels of breastfeeding.
\end{abstract}

Key Words: Breastfeeding, Influencing Variables

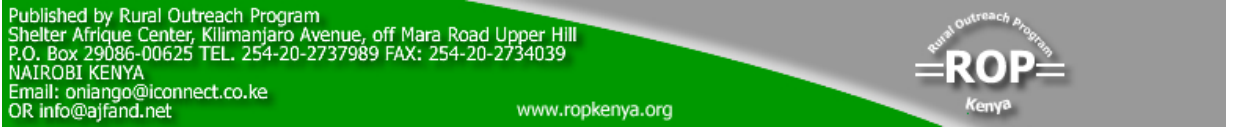


French

FACTEURS QUI INFLUENCENT LES PRATIQUES D'ALLAITEMENT AU SEIN DANS L'ETAT D'EDO AU NIGÉRIA

\section{RÉSUMÉ}

De nombreux ouvrages scientifiques ont démontré la supériorité du lait maternel sur les autres types de lait utilisés dans l'alimentation des bébés humains $[3,14,15]$. La petite enfance est caractérisée par une croissance rapide, une maturation des tissus et un développement des organes. L'allaitement au sein constitue la méthode idéale d'alimentation des bébés. Tous les besoins nutritionnels de la plupart de ces enfants sont satisfaits par le lait maternel et cela en quantités suffisantes et pendant une durée appropriée. Toutefois, au Nigeria, les jeunes bébés ne peuvent pas profiter d'une telle pratique à cause d'une initiation précoce inadaptée et de l'utilisation d'autres fluides affectant négativement le lait maternel [1,9]. Le but de cette étude était de déterminer les facteurs influençant les pratiques d'allaitement au sein dans l'Etat d'Edo au Nigeria. Les instruments utilisés comprenaient un questionnaire et un groupe de personnes interviewées. Les données ont été recueillies sur 600 mères choisies au hasard dont les bébés étaient âgés entre 4 et 24 mois, des mères qui ont visité quatre cliniques prénatales et pédiatriques. Les données obtenues ont été analysées en utilisant le pourcentage, la moyenne et l'écart type. Bien que les conclusions aient indiqué que 82 pour cent des mères pratiquaient l'allaitement au sein, 66 pour cent complétaient cette pratique avec le gruau de maïs et l'eau glucosée, et 14 pour cent utilisaient des infusions à base de plantes. Vingt pour cent seulement pratiquaient exclusivement l'allaitement au sein. Parmi les variables pouvant affecter les pratiques d'allaitement maternel, la plus importante était la proximité par rapport au bébé dont la note moyenne était de 4,63 (SD $\pm 0,66$ ) sur 5,00 tandis que la moins importante comprenait les antécédents familiaux avec une note moyenne de $2,32(\mathrm{SD} \pm \mathbf{0 , 9 2})$. Les conclusions de l'étude ont des implications sur les programmes d'éducation sanitaire ainsi que sur les pratiques d'allaitement au sein. Des efforts doivent être intensifiés afin d'apprendre aux futures mères l'importance et les avantages de l'allaitement maternel. L'initiative hospitalière UNICEF-OMS soucieuse des bébés doit aller au delà des hôpitaux universitaires et parvenir aux autres hôpitaux publics et privés. L'installation des crèches sur les lieux de travail ou sur les places de marché réduira la distance entre les bébés et leurs mères et par conséquent augmentera les niveaux d'allaitement au sein.

Mots clés : allaitement, variables influentes.

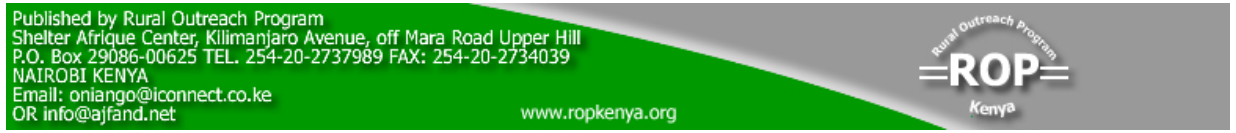




\section{INTRODUCTION}

The superiority of breast milk compared to other types of milk for the nourishment of the human infant offering better health benefits, has been established by various research publications $[3,14,15]$. The past few years have witnessed new and exciting observations worldwide concerning the biochemical, anti-infective, emotional and economic benefits of breastfeeding $[4,13,14]$. In an attempt to achieve successful breastfeeding globally by the year 2000, the World Health Organization (WHO) and United Nations International Children's Fund (UNICEF) launched the Baby Friendly Hospital Initiative (BFHI) in 1991. The BFHI is a global effort involving 160 countries, of which 95 of them are in the developing world where Nigeria belongs [15]. BFHI is a project through which the practice of exclusive breastfeeding is being supported, promoted and protected [9]. Breastfeeding activities are carried out worldwide in order to fulfill the WHO and UNICEF recommendation that infants be breastfed exclusively for six months and thereafter until 24 months. In view of the many benefits to mothers and children afforded by breastfeeding, governments have set goals and rates for breastfeeding practices [17].

The Nigerian government has earmarked six university teaching hospitals as BFHI centres, ie, Benin, Enugu, Maiduguri, Lagos, Jos and Port Harcourt, with the objective of reducing infant malnutrition, morbidity and mortality, as well as promoting the health of mothers. Since the inception of BFHI in 1991, a series of programmes, seminars, workshops and conferences - aimed at promoting breastfeeding practices - have been organized. The BFHI itself has proved to be an effective method of improving breastfeeding practices worldwide [11]. Despite all these efforts, the practice of breastfeeding has not reached the hundred percent mark. There is need for intensive nutrition education to mothers so as to enhance awareness about the importance of breastfeeding [6, 7, 8, and 12]. The BFHI may not have a positive effect since pregnant women in most developing countries still deliver their babies at home, or with a brief stay, if delivered in the hospital [4]. This scenario is the same in Nigeria [10]. The Nigerian Integrated Child Health Cluster Survey (ICHCS, 2003 ) indicated that a major area of need in infant breastfeeding was early initiation. Newborns are expected to be put to the breast within one hour of delivery. The survey indicated a decline from 56 per cent in 2000, to 34 per cent in 2002. The decision to breastfeed is very often influenced more by other factors, than by health considerations alone [5]. In order to design promotional activities and set national goals, breastfeeding rates need to be assessed [2].

The need to assess the level and factors influencing breastfeeding becomes compelling against the huge investment of international and Nigerian agencies, and the effect of such practices on the growing child and mother. This study was thus undertaken, to identify the level of and factors influencing breastfeeding practices among mothers of children aged 424 months in Benin City, Edo State, Nigeria.This paper presents the findings of the study. To facilitate this investigation, three research questions were raised:

1. What is the level of breastfeeding among women in Edo State?

2. To what extent do women practice exclusive breastfeeding?

3. What variables influenced breastfeeding practices?

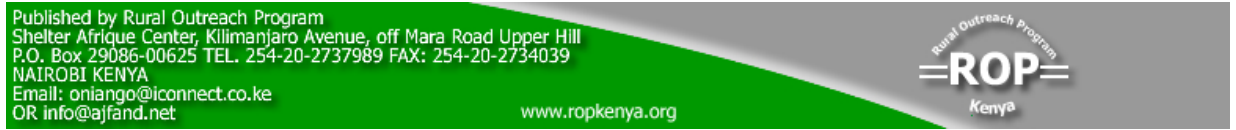




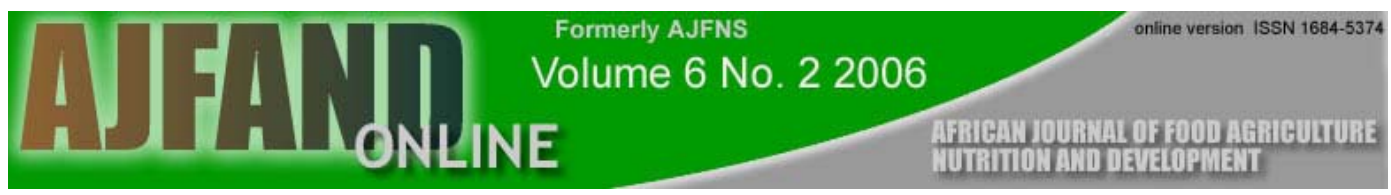

SUBJECTS AND METHODS

\section{Research Design}

A survey and focus group designs were used since there was no manipulation of the respondents and influencing variables.

\section{Area of Study}

Benin City, the capital city of Edo State was used for the study, principally because of its heterogeneous inhabitants.

\section{Sample and sampling technique}

600 mothers of children aged 4-24 months, visiting four antenatal and children clinics (one university teaching hospital, one state government owned and two privately owned), was randomly chosen. The following inclusion criteria were defined for participation:

1. Current breastfeeding

2. Must have heard at least a talk on the BFHI programme

954 randomly selected respondents signed the letter of consent, but 334 were dropped because they did not meet the selection criteria. After obtaining the informed verbal consent, the women were visited at the respective clinics for focus group discussions and the administration of the research instrument.

\section{Research Instrument}

Group interviewing was used to gather information since a standard survey instrument was administered to the group. The aim was to seek the respondents' opinions on breastfeeding, and to assess their eligibility to respond to the questionnaire. The questionnaire consisted of two sections $\mathrm{A}$ and $\mathrm{B}$ of 20 items, which was content validated in the University of Benin.

Section A dealt with the socio-demography, while section B elicited information relevant to the research trust. For reliability, the questionnaire was initially protested twice in an interval of two weeks to 60 women who were not among the final 600 respondents. The correlation coefficient of the two groups of scores was 0.86, indicative of a high reliability. Socio-demography was characterized by age, education, marital status, employment type and income. Influential variables in addition to the socio-demography were; family background, cultural affiliation, spouse influence and proximity to baby. 


\section{Data Collection and Statistical Analysis}

The researchers with the aid of two trained assistants administered and collected data from the respondents. Each clinic was visited twice on an agreed day with the respondents, where the questionnaires were completed and returned. Those who could not read were assisted by the research assistants to complete the questionnaire, and were not known to each other. The classified variables were presented in percentile, whereas the influential variables presented as mean \pm standard deviation (s.d.) using Excel based on a 5- point scale. The ratings were interpreted as: above 4.50, influential, 3.50-4.50 moderately influential, and below 3.50 not influential.

\section{RESULTS}

\section{Characteristics of participants}

The social and lifestyle characteristics of the participants are presented in Table 1.With respect to age, participation was highest amongst mothers 20 years and below. 40 per cent of the participants had no formal education and constituted the majority. The prevalence of those getting married was high among the participants. 61 per cent were either traders or self employed. In total, 61 per cent earned below 5,000 Naira $(\$ 1=$ 137 Naira) monthly, 11 percent and 38 percent, earned above 20,000 and between 520,000 , respectively.

\section{Rate of breastfeeding practices}

Table 2 shows the rate of breastfeeding practices of the participants. The majority of the women (82 per cent) breastfed, with only 18 per cent not breastfeeding. The main reason given for not breastfeeding was ill health. Of the 82 per cent that practiced breastfeeding, only 20 percent exclusively breastfed their infants up till six months. 61 per cent had added corn gruel and glucose water, while, 14 per cent added herbal brew as soon as the baby was born.

\section{Variables influencing breastfeeding}

Possible variables that may have influence breastfeeding practices were measured and reported in Table 3. The variables of interest were age of mother, education attained by mother, marital status, income, family background, proximity to baby, cultural affiliation and spouse influence. Proximity to baby was the most influential factor and the least weas cultural affiliation and family background.

\section{DISCUSSION}

The present study provides the level and influencing factors on breastfeeding practices of women resident in Benin City, Nigeria. Women in the study were randomly selected from four antenatal and children's clinics. The result of this study may not be generalized to represents the whole of Nigeria because of the limited coverage. The focus group discussion was primarily focused on identifying the respondents for this study. The majority of the women $(75 \%)$ did not believe in breastfeeding beyond the first year. The common reason given was that the baby could not get enough from

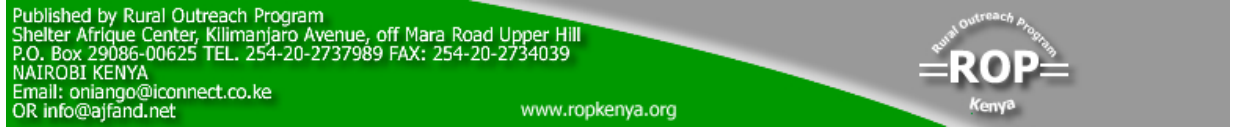


breast milk, and would soon be hungry. (This was in agreement with the ICHCS report [1]). The results of this study have shown that although the practice of breastfeeding may seem high, exclusive breastfeeding is still marginal. This study confirms previous studies carried out $[1,4,9$, and 16$]$.

Exclusive breastfeeding is compromised even when water is given to a child. This may be connected to the fact that in general, women of child-bearing age may not be adequately informed. The fact that educational attainment may not be a determinant of this practice does not preclude the fact that education still remains the most viable means of reaching everybody on the benefits of breastfeeding. The influential variables reported in this study were in agreement with other studies, while at variance with others $[11,16,17]$. Proximity to one's baby has been indicated as the most significant variable influencing breastfeeding practices. Although majority (61\%) of the respondents were lower income traders or self-employed, the market conditions may not have encouraged caring for their babies, hence such babies may have been left under the care of other persons. The global recession, which is also of national concern, has forced women back into the labor market immediately after giving birth.

The case of Nigeria is economic as the country's human and economic indicators continue to face enormous challenges $[18,19]$. The result is that mothers are forced to return to full time jobs with a shorter of breastfeeding span, which in most cases may not be exclusive $[4,17]$.

In summary, it is implied that although the level of breastfeeding may seem high, the practice of exclusive breastfeeding is marginal and, therefore, requires attention. It is, thus recommended that, added efforts in creating awareness on the benefits of breastfeeding be employed. The most influencing factor of breastfeeding practices reported in this study, is proximity to baby. The provision of crèches at the work place or market place will reduce the distance between babies and their mothers and subsequently increase the levels of breastfeeding.

\section{Acknowledgements}

Special thanks goes to Prof Wilna Oldewage-Theron, the Head of Hospitality and Tourism, Vaal University of Technology, Vanberbijlpark, South Africa, for her assistance and support. 
Table 1. Socio-demography of Respondents

\begin{tabular}{lll}
\hline Variable & $\mathrm{N}$ & $\%$ \\
& $\mathbf{6 0 0}$ & $\mathbf{1 0 0}$
\end{tabular}

Age (years)

$<20$

420

70

$25-35$

126

21

$>35$

54

9

Education

No formal

Primary

240

40

Secondary

$126-21$

Tertiary

$138-23$

$96-16$

\section{Marital Status}

Single Parenting

Married

$66-11$

$504 \quad 84$

Separated or Divorced

30

5

Employment Type

Traders or Self Employed $\quad 366 \quad 61$

$195 \quad 33$

Complete Housewives

39

33

Income Monthly (Naira)

$>20,000$

$66 \quad 11$

5-20,000

228

38

$<5000$

306

61

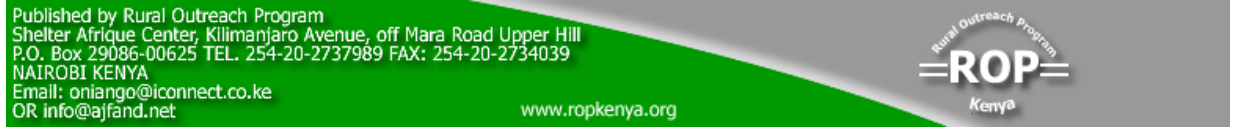


Table 2. Rate of Breastfeeding Practices

\begin{tabular}{lll}
\hline Level & $\mathrm{N}$ & $\%$ \\
& 600 & 100 \\
\hline Breastfeeding & 492 & 82
\end{tabular}

Not Breastfeeding

$108 \quad 18$

Type (Breastfeeding)

492

100

- Exclusive

96

20

- Breast milk/corn gruel/glucose

324

66

- Breast milk/herbal brew

72

14

$\underline{\text { Breastfeeding duration }}$

One year and below

450

75

Above one year

150

25

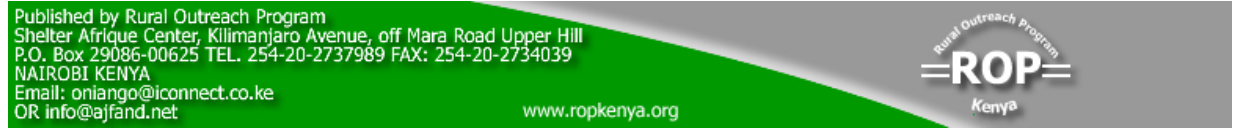


Table 3. Variables Influencing Breastfeeding

\begin{tabular}{lll}
\hline Variable & Mean $( \pm$ SD) & Remarks \\
\hline Age of Mother & $3.42( \pm 0.65)$ & Moderately Influential \\
Education & $3.64( \pm 0.78)$ & Moderately Influential \\
Marital Status & $3.80( \pm 0.83)$ & Moderately Influential \\
Income & $3.55( \pm 0.96)$ & Moderately Influential \\
Family Background & $2.32( \pm 0.92)$ & Not Influential \\
Proximity to Baby & $4.63( \pm 0.66)$ & Influential \\
Cultural Affiliation & $2.60( \pm 0.82)$ & Not Influential \\
Spouse Influence & $3.70( \pm 0.71)$ & Moderately Influential \\
\hline
\end{tabular}




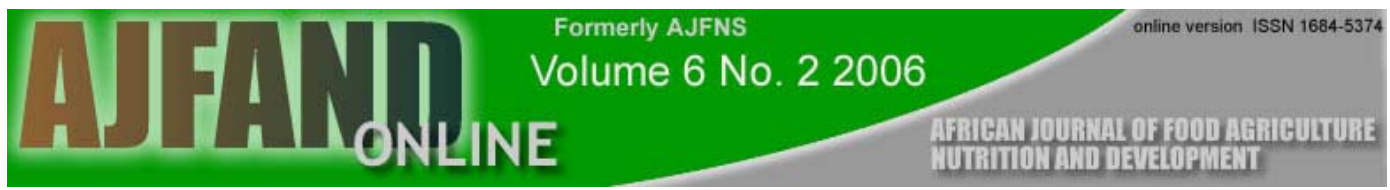

\section{REFERENCES}

1. Basic 11/ Nigeria: Integrated Child Health Cluster Survey (ICHCS), Arlington, USA, 2000.

2. Cattaneo A, Davanzo R and L Ronfani Are Data on the Prevalence and Duration of Breastfeeding Reliable? The Case of Italy. Acta Paediatrica, 2000; 89: 88-93.

3. Guise J-M and G Freed Resident Physicians' Knowledge of Breastfeeding and Infant Growth. Birth, 2000; 27 (1) 49-53.

4. Haider R, Ashworth A, Kabir I and SRA Huttley : Effect of Community Based Peer Counserllors on Exclusive Breastfeeding Practices in Dhaka, Bangladesh: A Randomized Controlled Trial. The Lancet, 2000;356: 1643-1647.

5. Henderson $\mathbf{L}$, Kitzinger $\mathbf{J}$ and $\mathbf{J}$ Green Representing Infant Feeding: Content Analysis of British Media Portrayal of Bottle Feeding and Breastfeeding. British Medical Journal, 2000; 321: 1196-1198.

6. Kar $\mathbf{M}$ and $\mathbf{R}$ De Breastfeeding practices - impressions from an urban community. Ind. J, Pub. Hlth, 1991; 35 (4) 93-96.

7. Kaur $\mathbf{P}$ and $\mathbf{N}$ Kaur Breastfeeding practices in Varanasi district (UP). Ind. J, Pub. Hlth, 1996; 40 (2) 52-53.

8.Nirojini BB, Payal $M$ and B Bandana A comparative study of breastfeeding practices among Kashmin Pandits and Dogras. Anthropologist. 2004;6 (4) 261-263.

9. Nwankwo BO and WR Brieger Exclusive Breastfeeding is undermined by Use of Other Liquids in Rural Southwestern Nigeria. J Trop Pediatr. 2002; 48 (2) 109-12.

10. Ogbonna C, Okolo SN and A Ezeogu Factors influencing exclusive breastfeeding in Jos, Plateau State, Nigeria. West Afr. J. Med. 2000; 19 (2) 107-10.

11. Ojofeitimi EO, Esimal OA, Owolabi OO, Oluwabusi O, Olaobaju OF and TO Olanuga: Breast Feeding Practices in Urban and Rural Health Centres: Impact of Baby Friendly Hospital Initiative in Ile-Ife, Nigeria. Nutrition and Health, 2000; 14: 119125.

12. Okolo Sn, Adewumi, YB and MC Okonji Current breastfeeding knowledge, attitudes and practices of mothers in 5 rural communities in savannah region of Nigeria. 1999; 45(1) 323-326.

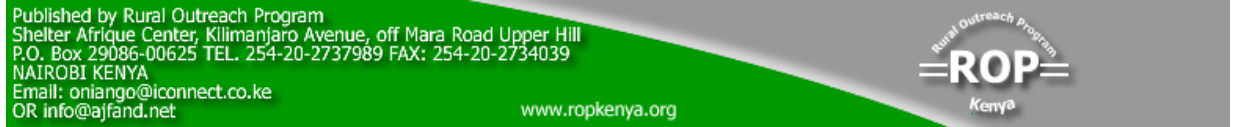


13. Salami LI Effect of Maternal Nutrition on Lactation Performance, Volume, Length and Frequency of Breastfeeding. In Breastfeeding Practices in Developing Countries (Ed. Atinmo, T) Nigeria Ambik Press, 2000; 34-40.

14. Uko-Aviomoh EE Advantages of Breastfeeding. In Breastfeeding Practices in Developing Countries (Ed. Atinmo, T) Nigeria Ambik Press 2000; 88-90.

15. UNICEF Newsletter on Baby Friendly initiative in Nigeria, Breastfeeding Quarterly, United Nation Publication, 1993; 1-5.

16. Vieira GO, Silva LR, Vieira TO, de Almeida and V Cabral Feeding Habits of Breastfed and Non-breastfed Children Up to 1 Year Old. J Pediatr., 2004; 80 (5) 41116.

17. Vogel A, Hutchison BL and EA Mitchell Factors Associated with the Duration of Breastfeeding. Acta Paediatrica, 1999 ; 88; 1320-1326.

18. World Bank World Development Report. Sustainable Development in a Dynamic World, Sub- Saharan Africa Regional Data from the WDI Database, Statistics Tables, 2003; 87-115.

19. World Health Organization The World Health Report Series, Geneva: World Health Organization, 2003. 